\title{
Determining the Possible Effect of Diabetes on the Nutritional Status of Hemodialysis Patients.
}

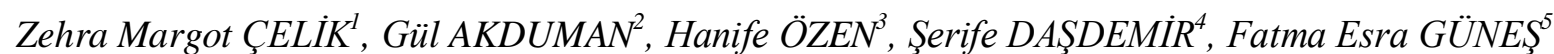

\begin{tabular}{|c|c|}
\hline & ABSTRACT \\
\hline $\begin{array}{r}\text { Corresponding Author } \\
\text { Zehra Margot ÇELIK } \\
\text { DoI } \\
\text { https://10.48121/jihsam.910490 }\end{array}$ & $\begin{array}{l}\text { Objective: Failure to maintain blood sugar control over } \\
\text { a long period of time in diabetic patients may cause } \\
\text { impairment of kidney functions. In addition to uremic } \\
\text { symptoms, impaired glucose metabolism causes difficulties } \\
\text { in obtaining adequate nutrition. The aim of this study is to } \\
\text { determine the possible impact of type } 2 \text { diabetes (T2DM) } \\
\text { on the nutritional status of hemodialysis }(H D) \text { patients. }\end{array}$ \\
\hline $\begin{array}{r}\text { Received } \\
06.04 .2021 \\
\text { Accepted } \\
17.06 .2021 \\
\text { Published Online } \\
27.10 .2021 \\
\text { Key Words } \\
\text { End-Stage Renal Disease } \\
\text { Diabetic Kidney Disease } \\
\text { Hemodialysis } \\
\text { Nutrition Status } \\
\text { Diet } \\
\text { Food } \\
\text { Nutrition }\end{array}$ & $\begin{array}{l}\text { Methods: Patients between the ages of } 18-65 \text { who } \\
\text { received HD treatment regularly were included in this } \\
\text { study. A demographic characteristics questionnaire was } \\
\text { applied to the patients and two 24-hour food recall records } \\
\text { were obtained. The patient's height, dry weight and fluid } \\
\text { gain were taken from their files. } \\
\text { Results: This study was conducted with a total of } 275 \\
\text { HD patients, } 33.1 \% \text { with and } 66.9 \% \text { without diabetes. The } \\
\text { median values of dietary energy (18.2 kcal/kg), } \\
\text { carbohydrate (2.1 g/kg), protein (46.2 g/kg) and fat }(0.7 \\
\text { g/kg) intake of the non-diabetic group was found to be } \\
\text { higher (p<0.05). The median of BMI was found higher in } \\
\text { the T2DM group than the non-diabetic group (p<0.05). A } \\
\text { weak positive correlation was found between the duration } \\
\text { of HD (years) and carbohydrate intake in patients with } \\
\text { T2DM (p<0.05) and a very weak positive correlation } \\
\text { between the hemoglobin levels and duration of } \\
\text { hemodialysis in the non-diabetic group ( } p<0.05 \text { ). } \\
\text { Conclusions: In this study, it was determined that } \\
\text { although HD patients with T2DM have less energy intake, } \\
\text { their BMI was higher; in addition, over time, a decrease in } \\
\text { dietary compliance triggers a deterioration in biochemical } \\
\text { parameters. }\end{array}$ \\
\hline
\end{tabular}

\footnotetext{
1 MSc, Faculty of Health Sciences, Marmara University, Istanbul. zmcelik @yahoo.com / Orcid Number: 0000-0002-4622-9252

${ }^{2}$ MSc, Faculty of Health Sciences, Marmara University, Istanbul. dytgulogren@gmail.com / Orcid Number: 0000-0001-5702-9478

${ }^{3}$ Graduate, Ministry of Youth and Sports, Karabük Youth and Sports Provincial Directorate, Karabük. Hanife.OZEN@gsb.gov.tr / Orcid Number: 0000-0003-1015-281X

${ }^{4}$ Graduate, Çamlık Medical Center, Istanbul. dytserifedasdemir@ gmail.com / Orcid Number: 0000-0001-9832-1117

${ }^{5} \mathrm{PhD}$, Faculty of Health Sciences, Marmara University, Istanbul. fegunes@ marmara.edu.tr / Orcid Number: 0000-0003-0334-7598
} 


\section{INTRODUCTION}

Chronic kidney disease (CKD) is the irreversible, gradual and progressive loss of kidney function (Width and Reinhard, 2009). The most common causes of CKD are diabetes, hypertension, glomerulonephritis and polycystic kidney diseases. At stage 5 , when the patients glomerular filtration rate is $<15 \mathrm{~mL} / \mathrm{min} / 1.72 \mathrm{~m} 2$, end-stage renal disease (ESRD) occurs, and the patient has to undergo renal replacement treatment (RRT); that is, dialysis or transplant. Dialysis is a method in which a machine filtrates the blood, serving as an artificial kidney. The most common dialysis method that has been used is hemodialysis (Mahan, 2011).

The incidence in the US of kidney failure that requires dialysis or transplant for ESRD ranks among the highest in the world (Saran et al., 2020). Since 2006, in the US the number of ESRD patients. has increased by 20,000 cases per year (4). In Turkey, there are approximately 30,000 dialysis-dependent patients with CKD (Akal Y1ldiz, 2012). The most commonly used treatment in patients with ESRD in Turkey is hemodialysis $(76.1 \%)$; this is followed by transplant (19.2\%) and peritoneal dialysis (4.7\%) (Seyhani et al., 2018)

Failure to control blood sugar over a long period of time in diabetic individuals causes a deterioration in kidney functions and often diabetic nephropathy. Diabetic nephropathy causes an acceleration of deterioration in kidney functions and can lead to ESRD. Indications of ESRD include abnormal albumin/protein excretion in the urine in patients, hypertension (HT) accompanying gradually decreasing renal functions, and continuous decrease in
GFR (Turker, 2019). Diabetic nephropathy (DNP) is an important cause of mortality in patients with diabetes. This complication can develop in patients with type 1 diabetes mellitus (T1DM) or type 2 diabetes mellitus (T2DM). Approximately $40 \%$ of the newly diagnosed ESRD patients in the USA are diabetic patients (Amos et al., 1997). According to National Nephrology, Dialysis and Transplantation Registry Report of Turkey 2018, when the etiology of patients starting HD in the last year was investigated it was found that $36.77 \%$ of the patients were diabetic (32.3\% T2DM, 4.44\% T1DM) (Suleymanlar et al., 2019). Thus, it can be seen that the most common cause of ESRD is diabetic nephropathy (DNP). In Europe and the USA, DNP develops in 30-50\% of patients with T1DM and $5-15 \%$ of patients with T2DM (Newman et al, 2005).

Nutritional problems in patients are caused by impaired glucose metabolism and the development of uremic symptoms arising from DNP. The restricted diet plans of kidney patients may result in the patient getting insufficient energy and nutrients. In this case, attempts to provide the necessary energy are met with high energy and low protein diet patterns. However, the presence of diabetes in addition to kidney damage causes difficulties in sufficient energy intake. Impaired insulin metabolism may accompany a loss of appetite, caused by uremic symptoms (Molitch et al., 2004). The aim of this study is to investigate the effects of T2DM as the etiology of kidney failure on the patient's nutritional status and related biochemical parameters.

\section{MATERIALS AND METHODS}

\section{Study Design and Sample Size}

This research is a cross-sectional descriptive study carried out in 8 centers - 5 separate dialysis centers and 3 hospitals with dialysis patients between January - June 2018 in Istanbul/Turkey. This study was approved by the Ethics Committee of Marmara University School of Medicine (Ethics committee number: 09.2017.033) and the research was conducted following the principles stated in the Helsinki Declaration. Before starting data collection, the necessary permission was obtained from the hospitals and centers.

Patients between the ages of 18 and 65, who regularly received treatment ( 2 or 3 times a week) were included in the study. A total of 275 volunteer patients were included and all questionnaires were filled out by the researchers in face-to-face bedsidepatient interviews.

\section{Demographic Characteristics Questionnaire}

The questionnaire on the demographic characteristics of the patients consists of 5 parts. Demographic information and questions about the patients' diseases were included in the first part of the questionnaire, with questions determining nutritional habits being included in the second part, anthropometric measurements in the third part, biochemical parameters being recorded in the fourth part, with the fifth part consisting of a 24-hour food recall record.

\section{Assessment of Anthropometric Measurements and Nutritional Status}

After obtaining the necessary permission, the patients height, dry weight and fluid gain were taken from their files. Using height and dry weight values, body mass index (BMI) was calculated for each patient. 
BMI was determined according to the World Health Organization classification. Patients were divided into three groups; underweight if BMI was $<18.50 \mathrm{~kg} / \mathrm{m} 2$, normal if BMI was $18.50-24.99 \mathrm{~kg} / \mathrm{m} 2$, overweight if BMI was $>25.00-29.99 \mathrm{~kg} / \mathrm{m} 2$, obese if BMI was $>30 \mathrm{~kg} / \mathrm{m} 2$ (WHO, 2020).

In order to evaluate nutritional status, a nondialysis 24-hour food recall record was obtained from the patients and this was repeated 15 days later. In this study, the average of two 24-hour food recall records was calculated per patient.

\section{Biochemical Parameters}

Routine blood tests of dialysis patients are carried out every month. After obtaining the necessary permission, the results of the blood tests performed in the preceding month were recorded from the patients files.

\section{Statistical Analysis}

The data obtained was analyzed with the SPSS (Statistical Package for Social Sciences Version 16.0) program. Normal distribution of the variables was checked by using the Kolmogorov Smirnov test. Categorical variables were described as frequency distributions and analyzed with the Chi-square $(\chi 2)$ test. It was determined that the data did not show a normal distribution. Differences of non-normal distributed continuous variables were compared by using the Mann-Whitney U test and Kruskall-Wallis test. A correlation between the groups was detected by using Spearmen Correlation tests. A p value of 0.05 or less was considered statistically significant. Energy and nutrient intakes were evaluated with the Nutrition Information System (BebiS 7.1) program.

\section{RESULTS}

This study was conducted with a total of 275 patients, 91 (33.1\%) with and $184(66.9 \%)$ without diabetes. The patients were separated into two groups; T2DM and Non-Diabetic. Women made up $40 \%$ of the patients and men $60 \%$. Only $13.8 \%$ of 275 patients were in the normal BMI range $(18.5-24.9 \mathrm{~kg} / \mathrm{m} 2)$. The education level of the majority of the patients $(81.9 \%)$ was primary school education and below. Sociodemographic distributions of the T2DM and non-diabetic groups were compared in Table 1. While there was no difference between the gender distribution of the patients with and without diabetes, there was a difference between the distribution according to body mass index and educational status $(\mathrm{p}<0.05)$. A statistically significant difference was observed between the BMI values of the T2DM and non-diabetic groups. The median $(27.4 \mathrm{~kg} / \mathrm{m} 2)$ of the BMI values of the T2DM group was statistically significantly higher than the non-diabetic group (24.6 $\mathrm{kg} / \mathrm{m} 2)(\mathrm{p}<0.05)$ (not shown in table).

Table 1. Comparison of socio-demographic characteristics of the groups.

\begin{tabular}{|c|c|c|c|c|c|}
\hline & \multicolumn{2}{|c|}{ T2DM } & \multicolumn{2}{|c|}{ Non-Diabetic } & \multirow[b]{2}{*}{$p$} \\
\hline & $\mathrm{n}$ & $\%$ & $\mathrm{n}$ & $\%$ & \\
\hline \multicolumn{6}{|l|}{ Gender } \\
\hline Female & 38.0 & 41.8 & 72.0 & 39.1 & \multirow{2}{*}{.69} \\
\hline Male & 53.0 & 58.2 & 112.0 & 60.9 & \\
\hline \multicolumn{6}{|l|}{$\mathrm{BMI}\left(\mathrm{kg} / \mathrm{m}^{2}\right)$} \\
\hline$<18.5$ & 7.0 & 17.5 & 39.0 & 45.9 & \multirow{4}{*}{$.00 * *$} \\
\hline $18.5-24.9$ & 15.0 & 37.5 & 23.0 & 27.1 & \\
\hline $25.0-29.9$ & 10.0 & 25.0 & 15.0 & 17.6 & \\
\hline$>30.0$ & 8.0 & 20.0 & 8.0 & 9.4 & \\
\hline \multicolumn{6}{|l|}{ Education } \\
\hline Primary school or less & 76.0 & 83.5 & 149.0 & 81.0 & \multirow{3}{*}{$.03 *$} \\
\hline Secondary and High School & 6.0 & 6.6 & 18.0 & 9.8 & \\
\hline University or above & 9.0 & 9.9 & 17.0 & 9.2 & \\
\hline Duration of CKD (median value) & \multirow{2}{*}{\multicolumn{2}{|c|}{$\begin{array}{c}4.0 \\
0.2-26.0\end{array}$}} & \multirow{2}{*}{\multicolumn{2}{|c|}{$\begin{array}{c}8.0 \\
0.1-42.0\end{array}$}} & \multirow{2}{*}{$.00 * *$} \\
\hline Min-max & & & & & \\
\hline Duration of hemodialysis & \multicolumn{2}{|c|}{$\begin{array}{c}3.0 \\
1.0-21.0\end{array}$} & \multicolumn{2}{|c|}{$\begin{array}{c}4.0 \\
1.0-30.0\end{array}$} & $.00 * *$ \\
\hline Total & 91.0 & 100.0 & 184.0 & 100.0 & \\
\hline
\end{tabular}

The comparison of dietary intake of macro and micronutrients of T2DM and non-diabetic patients is shown in Table 2. The median values of dietary energy are $1296.1 \mathrm{kcal}$ and $18.2 \mathrm{kcal} / \mathrm{kg}$ (U=692.9; $\mathrm{p}<0.05$ and $\mathrm{U}=605.6 ; \mathrm{p}<0.01)$, carbohydrate intake is $142.3 \mathrm{~g}$ and $2,1 \mathrm{~g} / \mathrm{kg}(\mathrm{U}=653.0 ; \mathrm{p}<0.01$ and $\mathrm{U}=574.2$; $\mathrm{p}<0,01)$, protein intake is $0.6 \mathrm{~g} / \mathrm{kg}(\mathrm{U}=6939.0 ; \mathrm{p}<0.05)$ and fat intake is $0,7 \mathrm{~g} / \mathrm{kg}(\mathrm{U}=689.3 ; \mathrm{p}<0.05)$ in nondiabetic patients which were found to be higher than diabetic individuals. 
When the meal frequencies of the two groups were compared, no statistically significant difference was found between the groups ( $\mathrm{p}>0.05)$.

Table 2. Comparison of macro and micronutrients dietary intake levels, fluid consumption, and body edema of the groups.

\begin{tabular}{|c|c|c|c|c|c|c|c|}
\hline & \multicolumn{3}{|c|}{ T2DM } & \multicolumn{3}{|c|}{ Non-Diabetic } & \multirow[t]{2}{*}{$p$} \\
\hline & Median & Min. & Max. & Median & Min. & Max. & \\
\hline Energy (kcal) & 1090.2 & 525.3 & 2544.5 & 1296.1 & 501.2 & 3602.5 & $.02 *$ \\
\hline Energy (kcal/kg) & 14.0 & 6.9 & 35.8 & 18.2 & 5.3 & 73.5 & $.00 * *$ \\
\hline Carbohydrate (g) & 118.3 & 38.1 & 394.8 & 142.3 & 11.3 & 450.0 & $.00 * *$ \\
\hline Carbohydrate (g/kg) & 1,5 & 0,3 & 4,7 & 2,1 & 0,1 & 8,4 & $.00 * *$ \\
\hline Protein $(\mathrm{g})$ & 41.3 & 10.0 & 130.1 & 46.2 & 8.40 & 123.7 & .25 \\
\hline Protein $(\mathrm{g} / \mathrm{kg})$ & 0.5 & 0.1 & 1.6 & 0.6 & 0.1 & 2.4 & $.02 *$ \\
\hline Dietary Fat (g) & 49.2 & 12.5 & 142.7 & 53.8 & 13.6 & 159.1 & .38 \\
\hline Dietary Fat (g/kg) & 0,6 & 0,1 & 2,0 & 0,7 & 0,1 & 3.2 & $.01 *$ \\
\hline Iron (mg) & 6.6 & 2.0 & 20.0 & 7.0 & 2.0 & 19.0 & .53 \\
\hline Calcium (mg) & 438.3 & 144.0 & 1057.0 & 437.4 & 91.0 & 1394.0 & .46 \\
\hline Phosphor (mg) & 682.0 & 266.0 & 1617.0 & 722.3 & 207.0 & 1790.0 & .56 \\
\hline Potassium (mg) & 1219.7 & 249.0 & 4451.0 & 1247.9 & 227.0 & 4084.0 & .81 \\
\hline Zinc (mg) & 5.20 & 1.70 & 15.70 & 6.10 & 1.10 & 19.0 & .09 \\
\hline Magnesium (mg) & 129.0 & 42.4 & 404.4 & 142.4 & 29.6 & 435.3 & .39 \\
\hline Sodium (mg) & 2592.6 & 479.3 & 8282.5 & 2780.9 & 526.3 & 8813.5 & .52 \\
\hline Vitamin $\mathrm{B}_{12}(\mathrm{mcg})$ & 2.0 & 0.0 & 9.6 & 2.3 & 0.0 & 71.7 & .36 \\
\hline Fluid Intake (L) & 1.0 & 1.0 & 4.0 & 1.0 & 0.0 & 5.0 & .63 \\
\hline Body Edema (kg) & 3.0 & 1.0 & 7.0 & 2.75 & 1.0 & 6.0 & .182 \\
\hline
\end{tabular}

Table 3 includes the comparison of biochemical parameters between the groups. Accordingly, it was found that the HbAlc and glucose values of the T2DM patients were higher than the non-diabetic patients $(\mathrm{U}=169.0 ; \mathrm{p}=0.01)$ while the creatinine and hemoglobin levels were higher in the non-diabetic group; this difference was statistically significant (respectively; $\mathrm{U}=583.7, \mathrm{p}=0.01$ and $\mathrm{U}=6815.5$, $\mathrm{p}=0.02$ ). The correlation of patients' daily fluid intake and the patient's body edema between two dialysis session had a weak positive correlation $(\mathrm{r}=0.24$; $\mathrm{p}<0.05)$ (not shown in table).

Table 3. Comparison of the biochemical parameters between the groups

\begin{tabular}{|c|c|c|c|c|c|c|c|}
\hline & \multicolumn{3}{|c|}{ T2DM } & \multicolumn{3}{|c|}{ Non-Diabetic } & \multirow{2}{*}{$p$} \\
\hline & Median & Min. & Max. & Median & Min. & Max. & \\
\hline Iron (ml/ng) & 58.0 & 8.0 & 195.0 & 58.5 & 5.0 & 192.0 & .47 \\
\hline Calcium (mg/dl) & 8.80 & 5.0 & 10.0 & 9.0 & 4.0 & 14.0 & .13 \\
\hline Phosphorus (mg/day) & 5.0 & 3.0 & 9.0 & 5.0 & 2.0 & 53.0 & .13 \\
\hline Potassium $(\mathrm{mEq} / \mathrm{L})$ & 5.0 & 3.0 & 8.0 & 5.0 & 3.0 & 6.0 & .97 \\
\hline $\mathrm{HbA} 1 \mathrm{c}(\%)$ & 7.0 & 4.0 & 11.0 & 5.0 & 4.0 & 6.0 & $.00 * *$ \\
\hline Glucose (mg/dL) & 146.0 & 70.0 & 538.0 & 88.0 & 53.0 & 235.0 & $.00 * *$ \\
\hline BUN (mg/dl) & 68.0 & 17.0 & 246.0 & 65.0 & 6.0 & 119.0 & .13 \\
\hline Creatinine $(\mathrm{mg} / \mathrm{dl})$ & 8.0 & 5.0 & 51.0 & 8.8 & 2.0 & 49.0 & $.00 * *$ \\
\hline Uric acid (mg/dl) & 6.0 & 3.0 & 12.0 & 6.4 & 3.0 & 13.0 & .60 \\
\hline Hemoglobin (g/dl) & 11.0 & 2.0 & 15.0 & 11.2 & 6.0 & 16.0 & $.02 *$ \\
\hline Albumin $(\mathrm{g} / \mathrm{dl})$ & 4.0 & 3.0 & 7.0 & 4.0 & 2.0 & 8.0 & .07 \\
\hline
\end{tabular}

The evaluation of the relationship between the duration of CKD diet and the duration of hemodialysis and the intake of energy and macronutrients is shown in Table 4. According to this data, there was no statistically significant relationship between the duration of a diet for CKD and the energy and micronutrients intake $(\mathrm{p}>0.05)$. A weak positive correlation was found between the duration of hemodialysis and dietary carbohydrate levels of the T2DM group $(\mathrm{p}<0.05)$. On the other hand, in both the T2DM group and the non-diabetic group, no relationship between hemodialysis duration and 
energy or with other macronutrients was found $(\mathrm{p}>0.05)$.

Table 4 also demonstrates the evaluation of the relationship between the duration of a diet for CKD and the duration of hemodialysis and biochemical parameters of the diabetic and non-diabetic groups. A weak correlation was found between the blood potassium level and duration of a diet for CKD of the patients with T2 DM ( $\mathrm{p}<0.05)$. A negative correlation was found between the uric acid levels and duration of hemodialysis of the patients with $\mathrm{T} 2 \mathrm{DM}(\mathrm{r}=-0.23$; $\mathrm{p}<0.05)$. A positive correlation was observed between the hemoglobin levels and duration of hemodialysis in the non-diabetic patients $(r=0.18 ; \mathrm{p}<0.05)$.

Table 4. Correlation of the durations of CKD diet and hemodialysis with the dietary energy, macronutrient intake and biochemical parameters

\begin{tabular}{|c|c|c|c|c|c|c|c|c|c|}
\hline \multirow{11}{*}{ 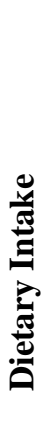 } & & \multicolumn{4}{|c|}{ Duration of a diet for CKD } & \multicolumn{4}{|c|}{ Duration of hemodialysis } \\
\hline & & \multicolumn{2}{|c|}{ T2DM } & \multicolumn{2}{|c|}{ Non-Diabetic } & \multicolumn{2}{|c|}{ T2DM } & \multicolumn{2}{|c|}{ Non-Diabetic } \\
\hline & & $\mathbf{r}$ & $p$ & $\mathbf{r}$ & $p$ & $\mathbf{r}$ & $p$ & $\mathbf{r}$ & $p$ \\
\hline & Energy (kcal) & .18 & .19 & .11 & .28 & .14 & .17 & -.02 & .75 \\
\hline & Energy (kcal/kg) & .19 & .18 & .14 & .17 & .19 & .06 & .05 & .43 \\
\hline & Carbohydrate (g) & .13 & .37 & .06 & .55 & .20 & .05 & .00 & .99 \\
\hline & Carbohydrate (g/kg) & .22 & .12 & .12 & .26 & .26 & $.01 *$ & .04 & .52 \\
\hline & Protein $(\mathrm{g})$ & .00 & .96 & .04 & .65 & -.01 & .90 & -.01 & .86 \\
\hline & Protein $(\mathrm{g} / \mathrm{kg})$ & .11 & .43 & .06 & .52 & .05 & .64 & .04 & .57 \\
\hline & Dietary Fat (g) & .20 & .16 & .12 & .25 & .08 & .43 & -.02 & .69 \\
\hline & Dietary Fat $(\mathrm{g} / \mathrm{kg})$ & .17 & .22 & .12 & .26 & .01 & .20 & .03 & .60 \\
\hline \multirow{11}{*}{ 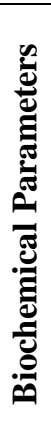 } & Iron (ml/ng) & .16 & .26 & -.02 & .79 & .01 & .92 & -.00 & .92 \\
\hline & Calcium (mg/dl) & .17 & .22 & -.17 & .10 & .12 & .23 & .08 & .26 \\
\hline & Phosphorus (mg/day) & -.02 & .87 & .02 & .83 & -.09 & .39 & .04 & .50 \\
\hline & Potassium (mEq/L) & .32 & $.02 *$ & .05 & .63 & .01 & .91 & -.04 & .52 \\
\hline & $\mathrm{HbA} 1 \mathrm{c}(\%)$ & .00 & .99 & -.06 & .54 & .09 & .39 & .04 & .58 \\
\hline & Glucose $(\mathrm{mg} / \mathrm{dL})$ & -.06 & .66 & .17 & .10 & -.08 & .43 & .04 & .53 \\
\hline & BUN (mg/dl) & .04 & .76 & -.06 & .57 & -.07 & .52 & -.09 & .20 \\
\hline & Creatinine $(\mathrm{mg} / \mathrm{dl})$ & -.01 & .91 & .00 & .99 & .06 & .54 & .02 & .78 \\
\hline & Uric acid (mg/dl) & -.22 & .12 & -.00 & .96 & -.23 & $.02 *$ & .05 & .49 \\
\hline & Hemoglobin $(\mathrm{g} / \mathrm{dl})$ & .03 & .79 & .05 & .61 & .12 & .24 & .18 & $.01 *$ \\
\hline & Albumin (g/dl) & .23 & .09 & -.18 & .08 & .03 & .76 & -.01 & .83 \\
\hline
\end{tabular}

\section{DISCUSSION}

In this study, the nutritional status of diabetic kidney patients was evaluated and the affecting parameters were highlighted.

When kidney damage occurs, comorbidity of diabetes is common. It is known that diabetes is an important cause of ESRD, and nearly half of the patients undergoing hemodialysis have a history of diabetes (8). This study was carried out with 275 hemodialysis patients, $91(33.1 \%)$ with and 184 $(66.9 \%)$ without diabetes.

In a study in which CKD prevalence and gender comparison were evaluated by region, CKD prevalence in the 3rd and 5th stages were higher in women than men (China, Beijing, Germany, Tibet, Finland, China, Korea, Turkey, Canada, Delhi, Portugal, Austria, Stockholm, Thailand, Poland, Italy, Spain, United States, Britain, France, Urumqi). On the other hand, it has been determined that in Singapore and Japan, there is a higher prevalence in men than women (Carrero et al., 2018). According to the United Nations database, $58 \%$ of CKD patients in the $3 \mathrm{rd}$ and 4th stages are women and $42 \%$ are men (Murphy et al., 2016; USRDS, 2016). The Turkey Chronic Kidney Disease Prevalence Survey (CREDIT) study demonstrates that chronic kidney disease (CKD) is more common in women $(18.4 \%)$ than men $(12.8 \%)$ and that the risk significantly increases with age (Suleymanlar et al., 2010). In our study groups, the distribution of genders was similar ( $p>0.05)$, however, unlike the CREDIT study, the majority of our study group was male $(60.0 \%) ; 58.2 \%$ of the T2DM group and $60.9 \%$ of the non-diabetic group was male.

The number of patients receiving renal replacement therapy in Turkey is gradually increasing; at the end of 2016, 74,475 patients were receiving renal replacement therapy. The prevalence of endstage renal disease is 933 per million populations and its incidence is 140. Diabetes is seen as the most important cause of end stage renal failure.6 Studies have emphasized that controlling blood sugar and body weight of kidney patients with diabetes is important in controlling patients' filtration levels. Changes in glomerular filtration rate can be seen in 
obese patients (Anders, 2018; Alicic et al., 2017). In a cohort study that collected 14 years of data, an association was found between increased BMI and progressive CKD (Herrington et al., 2017). In a study conducted by Biesenbach et al. it was shown that diabetic CKD patients had a BMI mean of $30 \pm 7$ $\mathrm{kg} / \mathrm{m} 2$ and non-diabetic patients had a BMI mean of $24 \pm 3 \mathrm{~kg} / \mathrm{m} 2$, it was found that the BMI was significantly higher in patients with T2DM (Biesenbach et al., 1999). Our T2DM group had higher percentages of overweight and obese patients than the non-diabetic group and the BMI mean of the T2DM group was $27.4 \mathrm{~kg} / \mathrm{m} 2$ as compared to 24,6 $\mathrm{kg} / \mathrm{m} 2$ for the non-diabetic group $(\mathrm{p}<0.05)$. The important mechanism here is that the levels of adipokine in the bloodstream increase with obesity, and this is associated with an increased filtration load, an increase in GFR and induction of nephron hypertrophy (D'Agati et al., 2016).

Another body weight problem is malnutrition. Patients may have a poor nutritional status due to dietary restrictions, loss of appetite or nausea. Nutritional deficiencies characterized by imbalances in protein energy expenditure can be triggered (Han et al., 2019). In a study it was found that only $7 \%$ of the patient in the diabetic group and $6 \%$ of the nondiabetic group had a BMI under $21 \mathrm{~kg} / \mathrm{m} 2$ (Biesenbach et al., 1999). In our study, $17.5 \%$ patients in the T2DM group and $45.9 \%$ in the non-diabetic group had a BMI under $18.5 \mathrm{~kg} / \mathrm{m} 2$. It was found that the BMI distribution in the groups was significantly different, with BMI being higher in the T2DM group $(p=0.00)$. Obesity is known to play an important role in the etiology of T2DM. Therefore, it is not surprising that the mean BMI of T2DM patients was higher than that of the non-diabetic group.

According to the KDOQI, the recommended energy (kcal/kg/day) intake for adults, whether diabetic or not, is $30-35 \mathrm{kcal} / \mathrm{kg} /$ day for patients 60 years of age and under, $35 \mathrm{kcal} / \mathrm{kg} /$ day for patients over 60 years of age; and the recommended protein consumption is $1.2 \mathrm{~g} / \mathrm{kg} /$ day (KDOQI, 2012). In a study conducted with CKD patients, it was emphasized that these patients suffer poor appetite, nausea and vomiting and have a poor quality of life when compared to the control group (Brown et al., 2015). In a study, it was found that energy intake was significantly lower than the level recommended by dietitians in both diabetic and non-diabetic kidney patients. On the other hand, protein intake was higher than recommended in both groups. It is emphasized that non-compliance with diet triggers decreases in GFR rate. A strong correlation was found between the dietary non-compliance of non-diabetic kidney patients and the decrease in GFR rate (Chen et al, 2017). In our study, there was no statistically significant relationship between the duration of a diet for $\mathrm{CKD}$ and the energy intake with the diet both T2DM and non-diabetic groups. Since low protein intake levels increase carbohydrate and fat intake, there is a risk of hyperglycemia and cardiovascular complications, especially for diabetic hemodialysis patients. The data obtained in a previous study found the energy intake of HD patients was 20.2 \pm 5.9 $\mathrm{kcal} / \mathrm{kg}$ /day while the protein intake was $0.8 \pm 0.25$ $\mathrm{g} / \mathrm{kg} / \mathrm{day}$. These values reveal that the energy and protein intake of hemodialysis patients in Turkey is much lower than the recommended level (Celik et al., 2019). Similarly, in a study conducted by Vijaya et al., it was found that before intervention the baseline protein consumption of HD patients was $0.7 \mathrm{~g} / \mathrm{kg} /$ day and $0.78 \mathrm{~g} / \mathrm{kg} /$ day (Vijaya et al., 2019). In this study we found that energy intake was $14.0 \mathrm{kcal} / \mathrm{kg} / \mathrm{day}$ for T2DM group and $18.2 \mathrm{kcal} / \mathrm{kg} /$ day for non-diabetic group $(\mathrm{p}<0.01)$, while protein intake was $0.5 \mathrm{~g} / \mathrm{kg} /$ day for the T2DM group and $0.6 \mathrm{~g} / \mathrm{kg} /$ day for the nondiabetic group $(p<0.05)$. These findings show that the energy and protein intake of the hemodialysis patients was lower than recommended; due to complications, this situation was even lower in the T2DM group.

Studies have emphasized that diabetic ESRD patients with diet adjustments have more edema than non-diabetic patients. Albumin, which is important in regulating the oncotic pressure in the bloodstream and maintaining fluid balance in the intracellular area, frequently decreases in diabetic nephropathy due to insufficient protein intake. For this reason, kidney patients with T2DM often experience edema (Mann et al., 2010; Gan et al., 2005; Nakagawa et al., 2009). However, in our study, no difference was found between the groups in terms of fluid intake or edema. We think that this is due to the higher sodium consumption of the non-diabetic group as compared to the T2DM group $(2780.9 \mathrm{mg} /$ day and $2592.6 \mathrm{mg} / \mathrm{day}$, respectively); there was also no difference between the albumin levels in either group.

Chronic under hydration and malnutrition are associated with irreversible kidney damage. In a study examining the relationship between meal frequency and CKD risk, those who consumed $<15$ meals/week had a higher risk of CKD than the group with $>15$ meals/week (Kim et al., 2020). In the current study when the meal frequencies of the two groups were compared, no statistically significant difference was found between the groups ( $\mathrm{p}>0.05)$.

Urea and creatinine levels are associated with an increase in blood glucose levels, which in diabetic patients indicates a decrease in kidney function (Pandya et al., 2016). Studies have shown that diabetic patients have high serum urea and creatine levels (Kamal, 2014; Deepa et al., 2011). However, in our study creatinine levels were found to be higher $(p<0.05)$ in the non-diabetic group. Also, a negative correlation was found between the uric acid levels and duration of hemodialysis of the patients with T2DM $(\mathrm{p}<0.05)$. As an expected result, blood glucose and $\mathrm{HbA1c}$ were higher in the T2DM group $(\mathrm{p}<0.05)$. 
The limitation of this study is that it was not an intervention study, so the nutritional status of HD patients was determined only by their diabetic and non-diabetic status. In addition, biochemical parameters were collected from patient files after necessary permissions were obtained and were limited to routine parameters.

\section{CONCLUSIONS}

In conclusion, it was determined that although HD patients with T2DM have a lower energy intake, their BMI was higher than the non-diabetic group. In addition, it has been observed that those who received HD treatment over many years developed dietary incompatibilities over time. It has been determined that the decrease in dietary compliance over time triggers the deterioration in biochemical parameters. In future studies, it is thought that determining the factors that make dietary compliance difficult for diabetic kidney patients and focusing on which components of the diet can be changed sustainably to optimize biochemical parameters will be beneficial.

\section{REFERENCES}

1. Akal Yıldız, E., (2012). Kronik Böbrek Yetmezliği ve Beslenme, Sağlık Bakanlığı, Türkiye Halk Sağlı̆̆ı Kurumu, Hastalıklarda Beslenme Bilgi Serisi, 2012.

2. Alicic, R.Z., Rooney, M.T., Tuttle, K.R., (2017). Diabetic kidney disease: challenges, progress, and possibilities.The Clinical Journal of the American Society of Nephrology, 12(12): 2032-2045

3. Amos, A.F., McCarty, D.J., Zimmet, P., (1997). The rising global burden of diabetes and its complications: Estimates and projections to the year 2010. Diabetic Medicine,14(5): 1-85.

4. Anders, H.J., Huber, T.B., Isermann, B., Schiffer, M., (2018). CKD in diabetes: diabetic kidney disease versus nondiabetic kidney disease. Nature Reviews Nephrology, 14(6): 361-377.

5. Biesenbach, G., Debska-Slizien, A., Zazgornik, J., (1999). Nutritional status in type 2 diabetic patients requiring haemodialysis. Nephrology, dialysis, transplantation, 14(3): 655-658.

6. Brown, M.A., Collett, G.K., Josland, E.A., Foote, C., Li, Q., Brennan, F.P., (2015). CKD in elderly patients managed without dialysis: survival, symptoms, and quality of life. The Clinical Journal of the American Society of Nephrology, 10(2): 260-268.

7. Carrero, J.J., Hecking, M., Chesnaye, N.C., Jager, K.J., (2018). Sex and gender disparities in the epidemiology and outcomes of chronic kidney disease. Nature reviews Nephrology, 14(3): 151.

8. Celik, Z.M., Islamoglu, A.H., Akduman, G., Gunes, F.E. (2019). Investigation of Nutritional Status of Hemodialysis Patients in Istanbul/Turkey. Advancements in Journal of Urology and Nephrology, 1: 1-5.

9. Chen, M.E., Hwang, S.J., Chen, H.C., Hung, C.C., Hung, H.C., Liu, S.C., Wu T.J., Huang, M.C., (2017). Correlations of dietary energy and protein intakes with renal function impairment in chronic kidney disease patients with or without diabetes. The Kaohsiung Journal of Medical Sciences, 33(5): $252-259$.

10. D'Agati, V.D., Chagnac, A., De Vries, A.P., Levi, M., Porrini, E., Herman-Edelstein, M., Praga, M., (2016). Obesity-related glomerulopathy: clinical and pathologic characteristics and pathogenesis. Nature Reviews Nephrology, 12(8): 453.

11. Deepa, K., Manjunatha, G.B.K., Oinam, S.D., Devaki, R.N., Bhavna, N., Asha, P., Naureen, A., (2011). Serum urea, creatinine in relation to fasting plasma glucose levels in type 2 diabetic patients. International Journal of Pharmacy and Biological Sciences, 1(3): 279-283.

12. Gan, H.B., Chen, M.H., Lindholm, B., Wang, T., (2005). Volume control in diabetic and nondiabetic peritoneal dialysis patients. International Urology and Nephrology, 37(3): 575579 .

13. Han, B.G., Lee, J.Y., Kim, J.S., Yang, J.W., (2019). Decreased Bioimpedance Phase Angle in Patients with Diabetic Chronic Kidney Disease Stage 5. Nutrients, 11(12): 2874.

14. Herrington, W.G., Smith, M., Bankhead, C., Matsushita, K., Stevens, S., Holt, T., Hobbs, F.D.R., Coresh, J., Woodward, M., (2017). Body-mass index and risk of advanced chronic kidney disease: prospective analyses from a primary care cohort of 1.4 million adults in England. PloS one, 12(3): e0173515.

15. Kamal, A., (2014). Impact of diabetes on renal function parameters. The Indian Journal of Fundamental and Applied Life Sciences, 4(3): 411-6.

16. Kim, Y.J., Yoon, J.H., Choi, H.S., Kim, C.S., Bae, E.H., Ma, S.K., Kim S. W., (2020). Meal Frequency and Skipping Breakfast Are Associated with Chronic Kidney Disease. Nutrients, 12(2): 331

17. Mahan, K., Escott-Stump, S., Raymond, J.L., (2011). Krause's Food \& the Nutrition Care Process. USA: Saunders.

18. Mann, J.F., Green, D., Jamerson, K., Ruilope, L.M., Kuranoff, S.J., Littke, T., Viberti, G., (2010). ASCEND Study Group. Avosentan for overt diabetic nephropathy. Journal of the American Society of Nephrology, 21(3): 527-535.

19. Molitch, M.E., DeFronzo, R.A., Franz, M.J., Keane, W.F., (2004). American Diabetes Association. Nephropathy in diabetes. Diabetes care, 27(1): 79-83.

20. Murphy, D., McCulloch, C.E., Lin, F., Banerjee, T., BraggGresham, J.L., Eberhardt, M.S., Morgenstern, H., Pavkov, M.E., Saran, R., Powe, N.R., Hsu, C.Y., (2016). Trends in prevalence of chronic kidney disease in the United States. Annals of Internal Medicine, 165: 473-481.

21. Nakagawa, T., Kosugi, T., Haneda, M., Rivard, C.J., Long, D.A., (2009). Abnormal angiogenesis in diabetic nephropathy. Diabetes, 58(7): 1471-1478.

22. Nation Kidney Foundation. KDOQI Clinical Practice Guideline for Diabetes and CKD: (2012) update. The American Journal of Kidney Diseases, 60(5): 850-886.

23. Newman, D.J., Mattock, M.B., Dawnay, A.B., Kerry, S., McGuire, A., Yaqoob, M., Hitman, G.A., Hawke, C., (2005). Systematic review on urine albumin testing for early detection of diabetic complications. Health Technology Assessment, 9(30): iiivi, xiii-163

24. Pandya, D., Nagrajappa, A.K., Ravi, K.S., (2016). Assessment and correlation of urea and creatinine levels in saliva and serum of patients with chronic kidney disease, diabetes and hypertension-a research study. Journal of Clinical and Diagnostic Research, 10(10): ZC58.

25. Saran, R., Robinson, B., Abbott, K.C., Bragg-Gresham, J., Chen, X., Gipson, D., Gu, H., Hirth, R.A., Hutton, D., Jin, Y., Kapke, A., Kurtz, V., Li, Y., McCullough, K., Modi, Z, Morgenstern, H., Mukhopadhyay, P., Pearson, J., Pisoni, R., Repeck, K., Schaubel, D.E., Shamraj, R., Steffick, D., Turf, M., Woodside, K.J., Xiang, J., Yin, M., Zhang, X., Shahinian, V., (2020). US Renal Data System 2019 Annual Data Report: Epidemiology of Kidney Disease in the United States. The American Journal of Kidney Diseases, 75(1): A6-A7.

26. Seyhani, N., Ates, K., Suleymanlar, G., (2018). Türkiye'de Renal Replasman Tedavilerinin Güncel Durumu: Türk Nefroloji Derneği Kayı Sistemi 2016 Yılı Özet Raporu. Turkish Journal of Nephrology, Dialysis and Transplantation, 27(2): 133-139. 
27. Suleymanlar, G., Ates, K., Seyhani, N., (2018). Ministry of Health and Turkish Society of Nephrology Joint Report. National Nephrology, Dialysis and Transplantation Registry Report of Turkey. Turkish Society of Nephrology, 2019: p.927.

28. Suleymanlar, G., Utas, C., Arinsoy, T., Ates, K., Altun, B., Altiparmak, M.R., Ecder, T., Yilmaz M.E., Çamsari T., Basi A., Odabas, A.R., Serdengeçti, K., (2010). Population-based survey of Chronic Renal Disease in Turkey-the CREDIT study. Nephrology Dialysis Transplantation, 26(6): 1862-1871.

29. Turker, P.F., (2019). Kronik Böbrek Yetmezliği Gelişen Diyabetli Bireylerde Beslenme Tedavisi. Beslenme ve Diyet Dergisi, 47: 74-81.

30. United States Renal Data System. Incidence, prevalence, patient characteristics, and treatment modalities. USRDS,
Annual Data Report: Epidemiology of Kidney Disease in the United States, 2018; 291-331.

31. United States Renal Data System. USRDS annual data report: epidemiology of kidney disease in the United States, 2016.

32. Vijaya, K.L., Aruna, M., Narayana, R.S., Mohan, P.R., (2019). Dietary counseling by renal dietician improves the nutritional status of hemodialysis patients. Indian Journal of Nephrology, 29: $179-85$.

33. WHO (World Health Organization), Body Mass Index (BMI) classifications. Web site. http://www.euro.who.int/en/healthtopics/disease-prevention/nutrition/a-healthy-lifestyle/bodymass-index-bmi. Accessed April 13, 2020.

34. Width, M., Reinhard, T., (2009). The clinical dietitian's essential pocket guide; Philadelphia: Williams \& Wilkins. 2009 . 